\title{
KRISTÓF ISTVÁN
}

\section{Az élve születés megítélése a helyszíni halottszemlén}

Újszülött halottszemléje esetében a helyszíni halottvizsgálat során törekedni kell alapvető kérdések megválaszolására.

Vetélést kell megállapítani, ha a magzat az anya testétől történt elválasztás után az élet semmilyen jelét nem adta, és 24 hétig vagy annál rövidebb ideig volt az anya méhében. Amennyiben a magzat kora nem állapítható meg, akkor beszélhetünk vetélésről, ha a magzat testtömege az 500 grammot vagy testhossza a 30 centimétert nem éri el. Ikerszülés esetén nem lehet vetélést megállapítani, ha legalább az egyik magzat élve született. Vetélésnél halottvizsgálati bizonyítványt nem kell kiállítani, a magzatot temetni nem kell, hanem erre a célra kijelölt sírhelytáblában kell elhelyezni.

A perinatális halál magában foglalja a halva születést és a születést rövid időn belül követő halálozást. Halva születésről beszélünk, amikor a halál a méhen belül a terhesség 24 . hete után következett be, vagy (ha a magzat korát nem lehet megállapítani) ha a méhen belül elhalt magzat hossza a 30 centimétert vagy tömege az 500 grammot eléri. Születést rövid időn belül követő halálozásról beszélünk, amikor a halál az újszülött megszületése utáni 168 órán belül következik be, függetlenül az újszülött hosszától vagy tömegétől. A perinatális halott esetében a perinatális halottvizsgálati bizonyítványt kell kitölteni a halottvizsgálat során, és kötelező kórbonctani vizsgálatot végezni. A halva született magzatot hozzátartozója eltemettetheti, a sírhelyen kereszt vagy fejfa is elhelyezhetö, és azon utónevet is fel lehet tüntetni.

A helyszínen fontos kérdésként vetődik fel, hogy a megszületett magzat élve született-e, ennek megválaszolása a helyszínen csupán a külvizsgálat alapján nem minden esetben lehetséges (bár megválaszolása a helyszínen fontos, mivel például halva született magzat büncselekmény tárgyaként nem szerepelhet), egyértelmü választ a boncolást is magában foglaló teljes körü vizsgálat adhat. A gyermeket - a fogantatástól eltelt időtartamtól függetlenül - élve születettnek kell tekinteni, ha az anya testétől történt elválasztása után az életnek bármilyen jelét adta. Az élve születés bizonyítékát szolgáltatják a megszületett magzat holttestének vizsgálatakor az anyától független önálló élet megkezdésének jelei, és a szülés után érvényesülő okok folytán beállt halálnak, illetve az életben történt szülés utáni bántalmazásnak a bizonyítása. A helyszíni vizsgálat 
során az élve születést bizonyíthatja az újszülött mozgása, széklet- és vizeletürítése stb. Az érett, életképes újszülött az első légvételek után erőteljesen felsír, gyengébben fejlett újszülött esetleg csak nyöszörög. Az érett újszülött betöltött 37-42. terhességi hétre születik, testtömege 2500 gramm vagy ezt meghaladó, fejkerülete $33-36 \mathrm{~cm}$, testhossza $48-52 \mathrm{~cm}$. Éretlen, 24. hetet el nem érő terhességből is születhet életjelenségeket mutató újszülött, életképessége azonban vitatható.

A magzat életképtelenségének oka éretlenség, fejlődési zavar és szülés elött vagy szülés közben szerzett sérülés, betegség is lehet. Az életképtelenség leggyakoribb oka az éretlenség.

Az éretlen magzat kisebb testtömegü és testhosszú, fülkagylóporcai fejletlenek, bőre vörhenyes színü, zsírszövete csekély, felületén sok gyapjú van. A kutacsok tágak, a koponyacsontok közötti varrathézagok szélesek, a fejbörön a hajzat gyér, finom, a szemöldökön és szempillákon egy-egy pelyhedzö szőrszál van, a körmök lágyak, a szembogárhártya sokszor még megvan, a herék nem szálltak le, a nagy szeméremajkak nem fedik a kisajkakat. A köldökzsinór a szeméremcsonthoz közel tapad. Az újszülött jelentősen csökkent életképességü, ha csak intenzív ellátás esetén tartható életben. A köldökcsonk vizsgálata elengedhetetlen, ez érett újszülött esetében a szegycsont kardnyúlványa és a szeméremízület között középen helyezkedik el, míg éretlen újszülöttben közelebb fekszik a szeméremízülethez. A hasfal és a köldökzsinór közötti bőrköldök érett újszülöttön egy centiméter hosszú. Fontos a köldökcsonk vizsgálata, az elvágás helye (a szeméremréstől való távolság utalhat arra, hogy ki vágta el a köldökzsinórt), jellege (metszés, vágás, szakítás vagy szakadás, harapás).

A magzat halála bekövetkezhet a méhen belül, közvetlenül vagy röviddel a szülés előtt külső beavatkozásoktól függetlenül is, anyai, magzati betegségek, illetve traumák vagy méhlepény-, köldökzsinór-rendellenességek miatt. A magzat méhen belüli elhalásának legbiztosabb jele a méhen belüli felázás, maceratio. A magzat halálát a szülés folyamata alatt leggyakrabban fulladás, a fej súlyos szülési megviseltetése, ritkábban elvérzés okozza.

Az újszülött halála bekövetkezhet természetes módon (éretlenség következményes életképtelenség, fejlődési rendellenesség, betegség, szülés közben szerzett sérülések, rohamos szülés okozta károsodások), ritkán az anya gondatlan cselekvése miatt (újszülött ápolásának elmaradása esetén irreverzibilis lehűlés, mechanikus légútelzáródás okozta fulladás, esetleg elvérzés, éhezés következhet be), és az anya tevőleges cselekvése során. Magyarországon utóbbi leggyakrabban fulladásos halál következtében jön létre (orr-, száj- 
nyílás nedves papírral történő befedése, folyadékba fojtás, vécébe, árnyékszékbe történő szülés, kútba dobás, kézzel történő megfojtás, ritkábban élve elásás). Gyakori a magára hagyás, ellátatlanság okozta kihülés, fulladás, ritkábban durva erőbehatások okozta sérülések (például megtaposás) szerepelnek a halál okaként.

A külvizsgálat során tanulmányozni kell az újszülött ellátottságának, ápolásának nyomait, a fürdetés utáni állapotot (magzatmáz, véres szennyeződések a kültakaróról hiányoznak), a köldökzsinór állapotát (szabályszerüen metszett, tépett stb.), ezek egyben az anya szülés utáni pszichés állapotára is utalnak. Az újszülöttön található sérüléseket el kell különíteni a szülési sérülésektől (például felkartörés), súlyos fejlödési rendellenességektől, szülési önsegély (a magzat előfekvő részein körülírtan jelentkező sérülések), rohamos szülés során létrejött és az újszülöttön a halál után kialakult postmortem elváltozásoktól, ez a helyszínen nem mindig egyszerü. Ha ismert, elengedhetetlen egyúttal a szülőnő vizsgálata is.

A szülőnő gyakran hivatkozik arra, hogy terhességéről nem tudott, azt nem ismerte fel, szülési fájdalmát székelési ingerként értékelte, ezért történt vécébe szülés, utóbbi eset a Legfelsőbb Bíróság 15. számú irányelve alapján „egymagában nem alapozza meg az ölési cselekmény elöre kitervelten elkövetettnek való minösitését".

Az újszülöttkori fizikai bántalmazások esetében a fejsérülések a leggyakoribb morbiditási és mortalitási okok. Az úgynevezett megrázottgyermekszindrómában klasszikusan keményburok alatti vérzés, retinális bevérzések, bordatörések és egyéb csonttörések fordulnak elö, de gyakran külvizsgálattal elváltozást nem észlelünk, neurológiai tünetek a gyanút felkelthetik.

\section{Esetismertetés}

Elözményi adatok

A rendelkezésünkre álló előzményi adatok szerint a szemle napján 14.40 körül szülőnőhöz hívtak mentőt egy budapesti családi házba. A helyszínen kivérzett sokkos állapotú szülőnőt és nejlonzacskóban egy elhunyt újszülöttet találtak. Elmondás szerint a nő a délelőtt folyamán szült, a mentőknek csak délután szóltak, mind az elhunyt újszülöttet, mind az anyát az illetékes kórház szülészeti-nőgyógyászati osztályára szállították, ahol az anyánál letamponálódott, nagy mennyiségü méhüri vérzést találtak. A szülőnö elmondása szerint az újszülött halva született, életjelenségeket nem mutatott. 
A 48 centiméter hosszú, 31 centiméter fejkerületü, 32 centiméter mellkerületü, 14 centiméter vállszélességü, leány újszülött holttestét a kórház kórbonctani osztályán, halotthütőben találjuk, kék nejlonzacskóban, fekvő testhelyzetben, mezítelenül, magzati pózban. A holttest bőre általában halvány, a háti területeken és az összefekvő területeken szürkés-zöldes magzatmáz volt megfigyelhető, a bőrön felázás egyértelmü jelei nem látszottak. A háti területeken ujjnyomásra nem halványuló, szederjes színü, közepes kiterjedésü hullafoltok voltak észlelhetök, a hullamerevség testszerte fennállt, kivéve a nyakizmokat. A hajzat 2,5-3 centiméter hosszú barna, a fül-, orrporcok tapinthatók voltak, a körmök a kezeken és a lábakon elérték az ujjbegyek vonalát. Az arc szabályos, arányos. A szemrések zártak, a kötőhártyák szederjesek, a bal szem kötőhártyája alatt az alsó áthajlási vonalakban szederjes kölesnyi, színes gombostüfejnyi petecses vérzések voltak megfigyelhetők. A szájrés zárt, amennyire betekinthető, a szájüreg üres volt. A köldökcsonk a has középvonalában 28 centiméter hosszú, vége egyenetlen széllel szakadt állapotú volt. A nagyajkak részben fedték a kisajkakat. A külső nemi szervek, a végbél környéke tiszta volt. A csontos váz tapintásra ép volt. Tekintettel arra, hogy a holttest hütőben volt elhelyezve, végbélhőmérséklet mérésére nem került sor.

Külsérelmi nyom: mindkét oldalon a halántékcsontok vetületében nagyjából szimmetrikusan, a fej két oldalán egyenként nagyjából csecsemőtenyérnyi területen a bőr kékes-szederjes elszíneződése, előbbi sérülésekkel egy vonalba eső területen, az orrgyök területének megfelelően, a bőr kékes-szederjes elszíneződése volt megfigyelhető.

A helyszínen lévő méhlepény 25 x 15 centiméter nagyságú volt, a köldökzsinór a tapadásától 10,5 centiméter hosszúságú egyenetlen szélű véggel végződött, másik felszíne durván egyenetlen vörhenyes-zöldes színü volt.

\section{Vélemény}

A helyszíni halottvizsgálat során a külvizsgálat alapján megállapítást nyert, hogy a leány újszülött érett volt, de esetében az élve, illetve halva születés tényét egyértelmüen megállapítani nem lehetett, azt csak a boncolás tudta tisztázni. A helyszínen a külvizsgálat alapján az volt véleményezhetö, hogy néhai nagyobb valószínüséggel élve született (tekintettel a külsérelmi nyomokra, szemkötőhártyák alatti elváltozásokra). A halál okára is csak va- 
lószínűségi vélemény volt adható, e szerint ha a boncoláskor bebizonyosodik az élve születés ténye, a leány újszülött halála, vélhetően eröszakos módon, az újszülött elégtelen ellátása, ellátatlansága, magára hagyása mellett kialakuló kihủlés, esetleg fulladás következtében a halottszemle megkezdése előtt 8-12 órával állhatott be. A halottvizsgálat alapján a helyszínen gyanú támadt az idegenkezüségre, előbbiekre tekintettel javaslat történt igazságügyi orvos szakértői boncolásra, szövettani és DNS-vizsgálattal kiegészítve.

Összefoglalóan elmondható, hogy kizárólag a helyszíni halottvizsgálat során az esetek jelentős részében az élve születettség tényére csak valószínüségi vélemény adható. A halálesetek tisztázása a helyszíni szemle, a nyomozati adatok, a helyszíni halottvizsgálat, a szülőnő vizsgálata, a boncolás és egyéb kiegészítő szakértői vélemények megállapításainak együttes értékelése alapján lehetséges.

\section{IRODALOM}

Sótonyi Péter (szerk.): Igazságügyi orvostan. Semmelweis Kiadó, Budapest, 2011 